\title{
Mesenteric panniculitis
}

\author{
Peter Alexander Newman, ${ }^{1}$ Hyeladzira Thahal, ${ }^{2}$ Baber Chaudhery ${ }^{1}$
}

1 Department of General Surgery, North Bristol NHS Trust, Bristol, UK

${ }^{2}$ Department of Radiology, North Bristol NHS Trust, Bristol, UK

\section{Correspondence to} Dr Peter Alexander Newman, alex-newman@doctors.org.uk

Accepted 11 March 2014
CrossMark

To cite: Newman PA, Thahal H, Chaudhery B. BMJ Case Rep Published online: [please include Day Month Year] doi:10.1136/bcr-2014203911

\section{DESCRIPTION}

A 62-year-old woman presented with a 3-day history of dull right-sided abdominal pain, radiating to her groin and exacerbated by movement. Her background included breast cancer, for which she had a wide local excision and hormonal treatment with tamoxifen and anastrozole, previous duodenal ulcers, vaginal hysterectomy and total thyroidectomy. Her abdomen was soft but tender; she was not guarding and no palpable masses were evident. Her $\mathrm{C}$ reactive protein (CRP) was elevated at 103 and CT scan demonstrated mesenteric panniculitis (figures 1 and 2). She was managed conservatively with analgesics and her symptoms and CRP settled.

'Misty mesentery' is a region of increased mesenteric fat density, compared with retroperitoneal fat, and gives a hazy impression. ${ }^{1}$ In this CT the Hounsfield Units (HU) of the small bowel mesentery were -53 compared with -118 HU for retroperitoneal fat. Misty mesentery is a non-specific feature on abdominopelvic CT scans as it simply represents increased density. This can be due to oedema, inflammation, haemorrhage, lymphoedema and neoplasia and these causes need to be excluded. $^{1}$

Mesenteric panniculitis represents the inflammatory stage in a spectrum of idiopathic primary mesenteric pathologies referred to as mesenteric

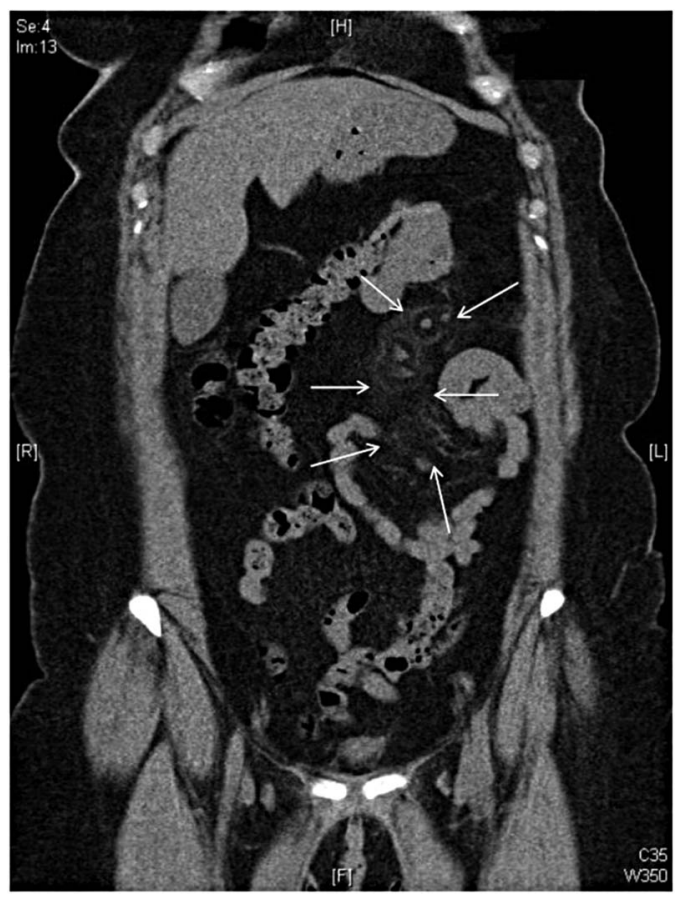

Figure 1 Non-contrast CT scan with a coronal view of the abdomen. Note the increased density in the small bowel mesentery on the left-hand side of the abdomen (arrowed), this is the 'misty mesentery' sign.

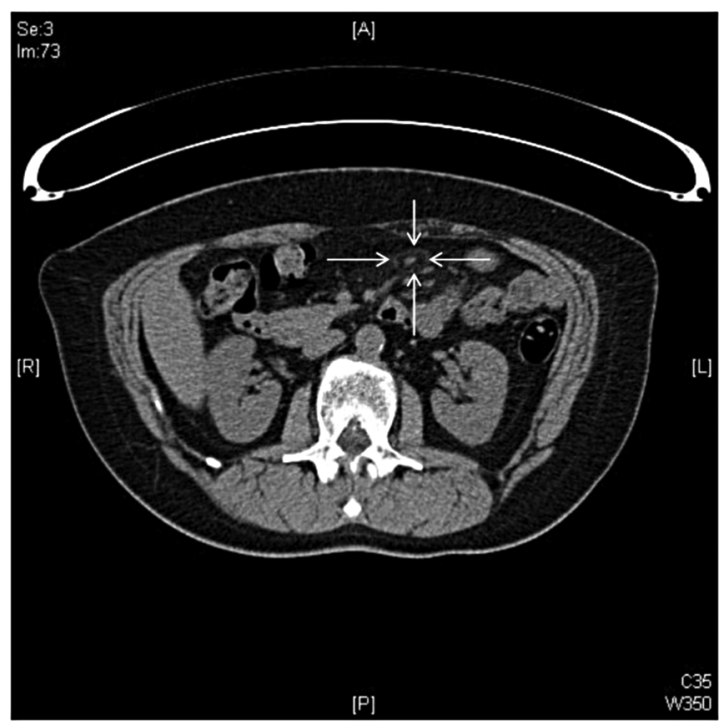

Figure 2 The same CT scan in the axial plane. Within the hyperattenuated region of mesentery there is a vessel with surrounding hypoattenuation (arrowed) — the 'fat halo' sign.

sclerosis. ${ }^{2}$ Histologically mesenteric sclerosis ranges from lipodystrophy to necrosis and fibrosis. The prevalence of mesenteric panniculitis on abdominopelvic CT scans is $0.6 \% .^{3}$ Typical features include a left-sided distribution, a 'fat halo' sign, nodules and a pseudotumorous hyperattenuation stripe. ${ }^{3}$ It is associated with malignancy, surgery, infection, autoimmune conditions and trauma and can be managed medically with analgesia and steroids. ${ }^{2}$

\section{Learning points}

- 'Misty mesentery' is a non-specific finding on CT scans and a cause for this should be sought.

- CT changes consistent with mesenteric panniculitis include positive findings; a left-sided distribution, 'fat-halo' sign, pseudotumorous hyperattenuation stripe, nodules and the absence of features suggesting haemorrhage, neoplasia, lymphoedema or other organ involvement.

Contributors BC identified and managed the case, read and revised the paper. $\mathrm{HT}$ identified the radiological diagnoses and provided expertise in the revision of the paper. PAN collected the information, looked at the literature and drafted and revised the paper. He was the guarantor.

Competing interests None.

Patient consent Obtained. 
Provenance and peer review Not commissioned; externally peer reviewed.

\section{REFERENCES}

1 McLaughlin PD, Filippone A, Maher MM. The "misty mesentery": mesenteric panniculitis and its mimics. AJR Am J Roentgenol 2013;200:W116-23.
2 Akram S, Pardi DS, Schaffner JA, et al. Sclerosing mesenteritis: clinical features, treatment, and outcome in ninety-two patients. Clin Gastroenterol Hepatol 2007:5:589-96.

3 Daskalogiannaki M, Voloudaki A, Prassopoulos P, et al. CT evaluation of mesenteric panniculitis: prevalence and associated diseases. AJR Am J Roentgenol 2000;174:427-31.

Copyright 2014 BMJ Publishing Group. All rights reserved. For permission to reuse any of this content visit http://group.bmj.com/group/rights-licensing/permissions.

BMJ Case Report Fellows may re-use this article for personal use and teaching without any further permission.

Become a Fellow of BMJ Case Reports today and you can:

- Submit as many cases as you like

- Enjoy fast sympathetic peer review and rapid publication of accepted articles

- Access all the published articles

- Re-use any of the published material for personal use and teaching without further permission

For information on Institutional Fellowships contact consortiasales@bmjgroup.com

Visit casereports.bmj.com for more articles like this and to become a Fellow 